\title{
ANALISIS PERBEDAAN PENGAKUAN PENDAPATAN MENGGUNAKAN METODE KONTRAK SELESAI DAN METODE PERSENTASE PENYELESAIAN
}

\author{
Alfonsus Herry Susanto \\ Program Studi Akuntansi \\ Fakultas Ekonomi Universitas Katolik Darma Cendika \\ Jalan Dr. Ir. H. Soekarno 201, Surabaya \\ Soedjono Rono \\ Program Studi Akuntansi \\ Fakultas Ekonomi Universitas Katolik Darma Cendika \\ Jalan Dr. Ir. H. Soekarno 201, Surabaya
}

\begin{abstract}
Percentage of Completion Method help the company in the financial system of the company in one period may have more than one contract because this method shows the income statement as fair. Revenue recognition with the Percentage of Completion Method using a proper approach to matching concept (compare the costs and revenue appropriately) is the most appropriate method for long term contracts because it can describe the income statement in each period can be reported proportionately and fairly. For short term contracts, companies can use the method of revenue recognition based on the Completed Contract Method or the Percentage of Completion Method with the terms of the contract occurred less than or not more than one accounting period, because if more than one period and using the Completed Contract Method, it can cause report income that is not fair. Keep in mind that the Percentage of Completion Method has the disadvantage that if there is reduction or additional work in a contract, the percentage of work progress to be recalculated, and if there is a change estimated total cost, so the revenue recognized in the previous year must recalculated.
\end{abstract}

\begin{abstract}
ABSTRAK
Metode Persentase Penyelesaian sangat membantu perusahaan dalam mengatur sistem keuangan perusahaan yang dalam satu periode dapat memiliki lebih dari satu kontrak kerja, karena metode ini memperlihatkan Laporan Laba Rugi secara wajar. Pengakuan pendapatan dengan Metode Persentase Penyelesaian menggunakan pendekatan proper matching concept (membandingkan biaya dan pendapatan secara layak) merupakan metode yang paling tepat untuk kontrak kerja jangka panjang, karena dapat menggambarkan Laporan Laba Rugi pada setiap periode secara proporsional dan dapat dilaporkan secara wajar. Untuk kontrak kerja jangka pendek, perusahaan dapat menggunakan metode pengakuan
\end{abstract}


pendapatan berdasarkan Metode Kontrak Selesai atau Metode Persentase Penyelesaian dengan ketentuan kontrak tersebut terjadi kurang dari atau tidak lebih dari satu periode akuntansi, karena jika lebih dari satu periode dan menggunakan Metode Kontrak Selesai, maka dapat menimbulkan Laporan Laba Rugi yang tidak wajar. Perlu diketahui bahwa Metode Persentase Penyelesaian memiliki kelemahan yaitu jika terjadi pekerjaan kurang ataupun pekerjaan tambah dalam suatu kontrak kerja, maka persentase kemajuan pekerjaan harus dihitung kembali, dan jika terjadi perubahan estimasi total biaya, maka pendapatan yang diakui di tahun sebelumnya harus dihitung kembali.

Keywords: percentage of completion method, the completed contract method.

\section{PENDAHULUAN}

Setiap perusahaan pada akhir periode mempunyai kewajiban untuk mempertanggungjawabkan dan melaporkan kinerjanya selama periode tersebut kepada pihak yang berkepentingan atau stakeholders melalui Laporan Keuangan. Salah satu Laporan Keuangan yang dapat menggambarkan hasil usaha perusahaan adalah Laporan Laba Rugi. Dalam penentuan besarnya laba rugi tidak hanya ditentukan dari besarnya pendapatan yang diakui, tetapi juga dilihat dari pengakuan dan pengukuran pendapatan yang diatur dalam Pernyataan Standar Akuntansi Keuangan (PSAK).

Perusahaan, khususnya yang memperoleh pendapatan dari kontrak yang bersifat jangka panjang dengan jangka waktu penyelesaian lebih dari satu periode akuntansi sering dihadapkan pada masalah pengakuan pendapatan dalam periode-periode selama jangka waktu penyelesaian kontrak jangka panjang dan penentuan bebanbeban yang muncul selama pelaksanaan yang berhubungan dengan kontrak jangka panjang yang masa penyelesaiannya lebih dari satu periode akuntansi tersebut. Dalam pengakuan pendapatan dan beban terdapat metode pengakuan yang menjadi acuan dalam pengakuannya.

Pendapatan dan beban harus diukur dengan wajar secara proporsional dan harus dipastikan sesuai dengan pengakuan pendapatan dan beban yang tertuang dalam Pernyataan Standar Akuntansi Keuangan (PSAK) Nomor 34 (Ikatan Akuntan Indonesia, 2012: 34.1). Penyimpangan dari pengakuan pendapatan dan beban yang tidak sesuai dengan Pernyataan Standar Akuntansi Keuangan (PSAK) ini akan menghasilkan Laporan Keuangan yang bias, khususnya pada Laporan Laba Rugi.

Secara umum untuk mengakui pendapatan yang diperoleh dari kontrak jangka panjang dapat menggunakan 2 metode, yaitu Metode Kontrak Selesai dan Metode Persentase Penyelesaian. Metode Persentase Penyelesaian dapat digunakan untuk mengakui pendapatan kontrak jangka panjang yang mempunyai waktu penyelesaian dalam satu periode akuntansi atau lebih dari satu periode akuntansi. Sedangkan Metode Kontrak Selesai hanya dapat digunakan untuk mengakui pendapatan yang diperoleh dari kontrak jangka panjang yang jangka waktu penyelesaiannya hanya dalam 
satu periode akuntansi dan tidak tepat digunakan untuk mengakui pendapatan dari kontrak jangka panjang yang jangka waktu penyelesaiannya lebih dari satu periode akuntansi.

Penelitian ini dimaksudkan untuk mengetahui sejauh mana perbedaan yang mungkin timbul terhadap penyajian Laporan Laba Rugi, apabila metode pengakuan pendapatan kontrak jangka panjang yang ada ini digunakan secara tidak tepat. Penelitian dilakukan dengan melihat kasus yang ada pada PT. Bangun Mitra Persada. Diketahui bahwa metode yang digunakan pada PT. Bangun Mitra Persada menggunakan Metode Kontrak Selesai untuk semua proyek yang dilaksanakan, baik itu proyek jangka pendek maupun proyek jangka panjang yang waktu penyelesaiannya lebih dari satu periode akuntansi. Seharusnya perusahaan menggunakan Metode Persentase Penyelesaian untuk proyek jangka panjang yang waktu penyelesaiannya lebih dari satu periode akuntansi, karena metode inilah yang dianjurkan di dalam Pernyataan Standar Akuntansi (PSAK) Nomor 34 tentang Kontrak Konstruksi.

\section{TINJAUAN PUSTAKA}

\section{Laporan Keuangan}

Laporan Keuangan merupakan ringkasan dari suatu proses pencatatan yang merupakan suatu ringkasan dari transaksi-transaksi keuangan yang terjadi selama tahun buku yang bersangkutan. Ikatan Akuntan Indonesia (2012: 5) menyatakan bahwa Laporan Keuangan merupakan struktur yang menyajikan posisi keuangan dan kinerja keuangan dalam sebuah entitas.

Menurut Munawir (2010: 5) Laporan Keuangan pada umumnya terdiri dari Neraca dan Perhitungan
Laba Rugi serta Laporan Perubahan Ekuitas. Ikatan Akuntan Indonesia (2012, 1-2) menyatakan Laporan Keuangan merupakan bagian dari proses pelaporan keuangan. Laporan Keuangan yang lengkap biasanya meliputi Neraca, Laporan Laba Rugi, Laporan Perubahan Posisi Keuangan, Catatan dan laporan lain, serta materi penjelasan yang merupakan bagian integral dari Laporan Keuangan.

\section{Perusahaan Jasa Konstruksi}

Menurut Peraturan Pemerintah Republik Indonesia Nomor 51 Tahun 2008 tentang Pajak Penghasilan atas Penghasilan dari Usaha Jasa Konstruksi dalam Prianthara (2010: 7) karakteristik perusahaan yang bergerak di bidang jasa konstruksi adalah sebagai berikut:

1. Jasa konstruksi adalah layanan jasa konsultasi perencanaan pekerjaan konstruksi, layanan jasa pelaksanaan pekerjaan konstruksi dan layanan jasa konsultasi pengawasan pekerjaan konstruksi.

2. Pekerjaan konstruksi adalah keseluruhan atau sebagian rangkaian kegiatan perencanaan dan/atau pelaksanaan beserta pengawasan yang mencakup pekerjaan arsitektural, sipil, mekanikal, elektrikal, dan tata lingkungan masing-masing beserta kelengkapannya untuk mewujudkan suatu bangunan atau bentuk fisik lain.

3. Perencanaan konstruksi adalah pemberian jasa oleh orang pribadi atau badan yang dinyatakan ahli yang profesional di bidang perencanaan jasa konstruksi yang mampu mewujudkan pekerjaan dalam bentuk dokumen perencanaan bangunan fisik lain. 
4. Pelaksanaan konstruksi adalah pemberian jasa oleh orang pribadi atau badan yang dinyatakan ahli yang profesional di bidang pelaksanaan jasa konstruksi yang mampu menyelenggarakan kegiatannya untuk mewujudkan suatu hasil perencanaan menjadi bentuk bangunan atau bentuk fisik lain.

5. Pengawasan konstruksi adalah pemberian jasa oleh orang pribadi atau badan yang dinyatakan ahli yang profesional di bidang pengawasan jasa konstruksi yang mampu melaksanakan pekerjaan pengawasan dari sejak awal pelaksanaan pekerjaan konstruksi sampai selesai dan diserahterimakan.

\section{Pendapatan}

Pendapatan atau (revenue) merupakan salah satu komponen yang sangat penting bagi suatu perusahaan, karena pendapatan merupakan jantung kehidupan bagi perusahaan. Pendapatan yang diterima yang akan digunakan untuk membiayai beban-beban yang dikeluarkan dalam menjalankan operasional perusahaan. Banyak pendapat yang dikemukakan mengenai definisi dari pendapatan.

Menurut Ikatan Akuntan Indonesia (2012: 23.2) definisi pendapatan adalah arus masuk bruto dari manfaat ekonomi yang timbul dari aktivitas normal entitas selama suatu periode jika arus masuk tersebut mengakibatkan kenaikan ekuitas, yang tidak berasal dari kontribusi penanam modal. Harahap (2011: 236) mengemukakan bahwa pendapatan adalah hasil penjualan barang dan jasa yang dibebankan kepada langganan atau mereka yang menerima.

Kieso et al. (2011: 955) menjelaskan definisi pendapatan sebagai manfaat ekonomi selama periode yang timbul dalam aktivitas normal saat arus kas masuk yang mengakibatkan kenaikan ekuitas, selain meningkat berkaitan dengan kontribusi dari pemegang saham. Menurut Stice et al. (2010: 161) pendapatan adalah arus atau produksi barang, memberikan jasa atau melakukan aktivitas lain yang merupakan aktivitas utama atau aktivitas sentral yang sedang berlangsung.

\section{Sumber Pendapatan}

Pada umumnya pendapatan perusahaan dapat dibedakan atas pendapatan operasi dan pendapatan non operasi. Pendapatan operasi adalah pendapatan yang diperoleh karena transaksi yang berkaitan langsung dengan operasional utama perusahaan yang bersifat rutin yaitu dengan adanya penjualan barang atau penyerahan jasa kepada pelanggan. Sedangkan pendapatan non operasi yaitu pendapatan yang bersifat insidensial seperti laba atas penjualan aktiva tetap dan lainnya.

Berikut ini adalah sumber-sumber pendapatan yang dapat menambah jumlah aktiva:

1. Transaksi modal dan pendanaan yang mengakibatkan adanya tambahan dana yang ditanamkan oleh pemegang saham dan pemegang obligasi atau kreditur.

2. Laba dari penjualan aktiva yang bukan berupa barang dagangan seperti aktiva tetap, surat-surat berharga atau penjualan anak atau cabang perusahaan.

3. Hadiah, sumbangan dan penemuan.

4. Revaluasi aktiva.

5. Penyerahan produk perusahaan, yaitu aliran hasil produk. 


\section{Pengukuran Pendapatan}

Santoso (2009: 347) menyatakan bahwa pendapatan diakui sebanding atau proporsional dengan tingkat penyelesaian yang diselesaikan pada tahun berjalan yaitu pengukuran masukan (input measure) atau pendekatan biaya. Pengukuran tingkat penyelesaian suatu kontrak konstruksi dilakukan berdasarkan masukan yang sesungguhnya terjadi dengan total masukan yang diperkirakan diperlukan untuk menyelesaikan kontrak tersebut. Masukan tersebut dapat berupa biaya (cost), jam kerja (working hours), pemakaian bahan (raw material used) atau dasar masukan lainnya. Ada 2 (dua) metode dalam pengukuran masukan yaitu:

a. Metode biaya ke biaya (cost to cost method).

Pengukuran tingkat penyelesaian suatu kontrak didasarkan pada perbandingan biaya yang sesungguhnya dikeluarkan (yang sesungguhnya terjadi) dengan total taksiran biaya untuk penyelesaian kontrak tersebut.

b. Metode usaha yang dicurahkan (effort expended method).

Pengukuran tingkat penyelesaian suatu kontrak diukur dengan perbandingan masukan lainnya selain biaya (misalnya: jam mesin, jam kerja langsung atau pemakaian bahan) yang sesungguhnya terjadi dengan taksiran total masukan tersebut untuk menyelesaikan kontrak tersebut.

\section{Metode Pengakuan Pendapatan}

Ada beberapa metode pengakuan pendapatan yang dapat digunakan, yaitu:

1. Menurut Ikatan Akuntan Indonesia (2012: 34.5) dalam Pernyataan
Standar Akuntansi Keuangan (PSAK) Nomor 34 paragraf 21, jika hasil kontrak konstruksi dapat diestimasi secara andal, maka pendapatan kontrak dan biaya kontrak yang berhubungan dengan kontrak konstruksi diakui masing-masing sebagai pendapatan dan beban dengan memperhatikan tahap penyelesaian aktivitas kontrak pada tanggal akhir periode pelaporan.

2. Menurut Ikatan Akuntan Indonesia (2012: 34.5) dalam Pernyataan Standar Akuntansi Keuangan (PSAK) Nomor 34 paragraf 22, dalam hal kontrak harga tetap, hasil kontrak konstruksi dapat diestimasi secara andal jika semua kondisi berikut ini dapat terpenuhi yaitu:

a. Total pendapatan kontrak dapat diukur secara andal.

b. Kemungkinan besar manfaat ekonomi yang berhubungan dengan kontrak tersebut akan mengalir ke entitas.

3. Menurut Ikatan Akuntan Indonesia 92012: 34.5) dalam Pernyataan Standar Akuntansi Keuangan (PSAK) Nomor 34 paragraf 23 pada kontrak biaya-plus, hasil kontrak konstruksi dapat diestimasi secara andal jika kondisi terpenuhi yaitu kemungkinan besar manfaat ekonomi yang berhubungan dengan kontrak tersebut akan mengalir ke entitas.

4. Santoso (2009: 340-341) menyatakan bahwa sesuai dengan konsep akuntansi akrual (accrual accounting), prinsip pengakuan pendapatan tidak dikaitkan pada saat kapan uang kas diterima, karena pada prinsipnya pendapatan dan keuntungan diakui bila 2 (dua) 
kriteria seperti berikut ini dipenuhi, yaitu :

a. Direalisasi atau dapat direalisasi, artinya pendapatan dan keuntungan tersebut telah direalisasikan.

b. Telah direalisasikan, artinya pendapatan keuntungan tersebut telah dihasilkan karena sebagian besar dari proses untuk menghasilkan laba yang telah diselesaikan.

5. Prihadi (2011: 13) menyatakan bahwa revenue recognition (pengakuan pendapatan) menuntut pengakuan pendapatan pada saat produk (barang atau jasa) sudah diserahkan. Pendapatan dikatakan telah direalisasi (realized) jika barang atau jasa telah dipertukarkan dengan kas. Pendapatan dikatakan dapat direalisasi (realizable) apabila aktiva yang diterima dapat segera dikonversi menjadi kas. Pendapatan dianggap telah dihasilkan atau telah terjadi (earned) apabila perusahaan telah melakukan apa yang seharusnya dilakukan untuk mendapatkan hak atas pendapatan tersebut.

\section{Biaya dan Beban}

Dalam Laporan Keuangan seringkali terdapat istilah beban dan biaya dengan pengertian berbeda. Beban sering didefinisikan dalam arti biaya yang habis terpakai (cost expiration) atau lokasi biaya. Berikut adalah beberapa definisi beban dan biaya:

a. Menurut Ikatan Akuntan Indonesia dalam Martani (2012: 44) beban adalah penurunan manfaat ekonomi selama satu periode akuntansi dalam bentuk arus keluar atau berkurangnya aset atau terjadinya liabilitas yang mengakibatkan penu- runan ekuitas yang tidak menyangkut pembagian kepada penanam modal.

b. Supriyono (2011: 16) menyatakan bahwa biaya adalah harga perolehan yang dikorbankan atau digunakan dalam rangka memperoleh penghasilan (revenues) dan akan dipakai sebagai pengulang penghasilan.

c. Bastian dan Nurlela (2010: 4) mendefinisikan bahwa biaya adalah pengorbanan sumber ekonomis yang diukur dalam satuan uang yang telah terjadi untuk mencapai tujuan tertentu.

\section{Metode pengakuan Beban}

Pengakuan suatu beban biasanya bersamaan dengan digunakannya barang atau jasa dalam proses memperoleh pendapatan, tetapi dapat juga setelah penggunaan barang dan jasa atau dalam keadaan luar biasa dapat juga sebelum penggunaan barang dan jasa. Saat pengakuan beban ditentukan oleh pendapatan laba yang dipakai perusahaan.

Menurut Ikatan Akuntan Indonesia (2012: 34.5) dalam Pernyataan Standar Akuntansi Keuangan (PSAK) Nomor 34 paragraf 22 dalam hal kontrak harga tetap, hasil kontrak konstruksi dapat diestimasi secara andal jika kondisi berikut terpenuhi:

a) Baik biaya kontrak untuk menyelesaikan kontrak maupun tahap penyelesaian kontrak pada akhir periode pelaporan dapat diukur secara andal.

b) Biaya kontrak yang dapat diatribusi pada kontrak dapat diidentifikasi dengan jelas dan diukur secara andal, sehingga biaya kontrak aktual dapat dibandingkan dengan estimasi sebelumnya. 
Menurut Ikatan Akuntan Indonesia dalam Martani (2012: 47) pengakuan beban dinyatakan sebagai berikut:

- Beban diakui dalam Laporan Laba Rugi Komprehensif, jika penurunan manfaat ekonomi masa depan yang berkaitan dengan penurunan aset atau peningkatan liabilitas telah terjadi dan dapat diukur dengan andal.

- Beban diakui dalam Laporan Laba Rugi atas dasar hubungan langsung antara biaya yang timbul dan pos penghasilan tertentu yang diperoleh (matching expense of costs with revenues).

- Beban diakui dalam Laporan Laba Rugi Komprehensif atas dasar prosedur alokasi yang rasional dan sistematis dalam periode akuntansi yang menikmati manfaat. Hal ini sering diperlukan dalam pengakuan beban yang berkaitan dengan penggunaan aset seperti aset tetap, goodwill, paten, merek dagang. Dalam kasus semacam itu, beban ini disebut penyusutan atau amortisasi.

- Beban segera diakui dalam Laporan Laba Rugi Komprehensif kalau pengeluaran tidak menghasilkan manfaat ekonomi masa depan atau jika manfaat ekonomi masa depan tidak memenuhi syarat, atau tidak lagi memenuhi syarat, untuk diakui dalam Neraca sebagai aset.

- Beban juga diakui dalam Laporan Laba Rugi Komprehensif pada saat timbul kewajiban tanpa adanya pengakuan aset, seperti apabila timbul liabilitas akibat garansi produk.

Perbandingan Metode Kontrak Selesai dengan Metode Persentase Penyelesaian

1. Metode Persentase Penyelesaian
Ikatan Akuntan Indonesia (2012: 34.5) dalam Pernyataan Standar Akuntansi Keuangan (PSAK) Nomor 34 paragraf 24 dan 25 menyatakan suatu perusahaan akan mengakui pendapatan dan beban sesuai dengan tingkat kemajuan penyelesaian kontrak dan tidak memisahkan pengakuan unsur ini sampai kontrak selesai. Untuk mengukur kemajuan penyelesaiannya menggunakan metode biaya ke biaya dengan rumus sebagai berikut:

Biaya yang terjadi

s.d. akhir periode

Taksiran Total Biaya

\section{Metode Kontrak Selesai}

Santoso (2009: 344) menyatakan bahwa pendapatan diakui hanya pada saat kontrak diselesaikan (pada saat tingkat penyelesaian kontrak mencapai 100\%). Dalam mengakui pendapatannya berdasarkan atas kemajuan fisik proyek yang dijadikan dasar pemberi kerja untuk pembayaran termin pada periode berjalan.

\section{METODE PENELITIAN Objek atau Subjek Penelitian}

Subjek dari penelitian ini adalah PT. Bangun Mitra Persada yang bertempat di Jalan Pandegiling Nomor 63, Surabaya. Bidang pekerjaan yang dikerjakan oleh PT. Bangun Mitra Persada adalah sebagai kontraktor. Objek dari penelitian ini adalah Laporan Laba Rugi proyek Block Office di Batu, Malang.

\section{Pendekatan Penelitian dan Sumber \\ Data \\ Jenis Penelitian \\ Jenis penelitian yang diguna- kan dalam penelitian ini merupakan}


penelitian deskriptif kualitatif, karena menggambarkan keadaan objek penelitian atau masalah yang ada dalam penelitian, yang dalam penelitian ini masalah metode pengakuan pendapatan antara Metode Kontrak Selesai dan Metode Persentase Penyelesaian dalam penyajian Laporan Keuangan.

\section{Sumber Data}

Sumber data yang digunakan dalam penelitian ini adalah sebagai berikut:

a) Data primer yaitu data yang langsung diperoleh dari perusahaan melalui wawancara langsung

b) Data sekunder yaitu data yang diambil dari arsip keuangan perusahaan

\section{Teknik pengumpulan data}

Teknik pengumpulan data yang digunakan dalam penelitian ini dilakukan dengan pengumpulan data pada perusahaan. Teknik pengumpulan data dilakukan sebagai berikut:

a) Wawancara atau interview.

b) Observasi.

c) Dokumentasi.

\section{Satuan kajian}

adalah:

Satuan kajian yang dipakai

1. Metode Kontrak Selesai (Completed Contract Method)

2. Metode Persentase Penyelesaian (Percentage of Completion Method).

\section{Teknik Analisis Data}

Dalam usaha mencari dan mengumpulkan data untuk penelitian ini digunakan teknik analisis sebagai berikut:
1) Collecting yaitu mengumpulkan data yang meliputi pendapatan dan biaya pengerjaan proyek.

2) Classification yaitu mengklasifikasikan data tentang proyek jangka panjang beserta nilai kontrak yang disetujui dan jangka waktu pengerjaannya, mengidentifikasi persentase penyelesaian yang ditentukan dari progres fisik, mengidentifikasi rencana anggaran biaya dan biaya aktual yang dikeluarkan.

3) Analyzing yaitu melakukan analisis terhadap hasil penelitian untuk menentukan metode pengakuan pendapatan yang paling sesuai dengan proyek jangka panjang dalam rangka penyajian laporan keuangan yang wajar.

\section{HASIL PENELITIAN \\ Deskripsi Hasil Penelitian}

Pengakuan pendapatan yang digunakan perusahaan ini adalah dengan menggunakan Metode Kontrak Selesai berdasarkan progress lapangan. Metode ini digunakan untuk semua proyek, baik itu proyek jangka pendek maupun proyek jangka panjang. Jadi hanya ada laporan Neraca dan tidak ada Laporan Laba Rugi apabila proyek belum selesai $100 \%$.

\section{PEMBAHASAN DAN ANALISIS DATA}

\section{Analisis Masalah}

Berikut ini adalah seperti terlihat pada Tabel 1 rekapitulasi kontrak kerja PT. Bangun Mitra Persada pada bulan Maret tahun 2014 sampai dengan bulan Desember tahun 2015 dengan mengambil contoh salah satu proyek yang ada di Batu, kota Malang. 
Tabel 1

Rekapitulasi dari Nilai Kontrak

Rp. 40.121.843.238,00

Proyek Block Office Batu

\begin{tabular}{|c|l|c|}
\hline No. & Keterangan & Nominal (Rp.) \\
\hline 1 & DPP & $37.497 .049 .755,14$ \\
\hline 2 & PPN & $3.749 .704 .975,51$ \\
\hline 3 & PPh. 3\% & $1.124 .911 .492,65$ \\
\hline 4 & Retensi 5\% & $2.006 .092 .161,9$ \\
\hline & Total & $40.121 .843 .238,00$ \\
\hline
\end{tabular}

Perbandingan antara Metode Pengakuan Pendapatan Berdasarkan Metode Kontrak Selesai dan Metode Persentase Penyelesaian

Biaya-biaya yang sesungguhnya terjadi, baik biaya langsung maupun biaya tidak langsung yang dibebankan, pengajuan uang muka dan termin, serta pembayaran dari tahun 2014 sampai dengan tahun 2015 nampak seperti terlihat pada Tabel 2.

Tabel 2

Rekapitulasi Biaya serta Penerimaan Uang Muka dan Termin Proyek Block Office Batu

\begin{tabular}{|c|c|c|c|}
\hline Tahun & Keterangan & $\begin{array}{c}\text { Biaya yang } \\
\text { terjadi (Rp) }\end{array}$ & $\begin{array}{c}\text { Penerimaan } \\
\text { Uang Muka } \\
\text { dan Termin } \\
\text { (Rp) }\end{array}$ \\
\hline $\mathbf{2 0 1 4}$ & $\begin{array}{c}\text { Uang muka } \\
10 \%\end{array}$ & - & $4.012 .184 .323,8$ \\
\hline $\mathbf{2 0 1 4}$ & $\begin{array}{c}\text { Termin I } \\
29,3 \%\end{array}$ & $12.926 .583 .877,34$ & $11.755 .700 .068,73$ \\
\hline $\mathbf{2 0 1 4}$ & $\begin{array}{c}\text { Termin II } \\
29,6 \%\end{array}$ & $12.273 .646 .323,89$ & $11.876 .065 .598,45$ \\
\hline $\mathbf{2 0 1 5}$ & $\begin{array}{c}\text { Termin III } \\
15,5 \%\end{array}$ & $8.335 .766 .906,22$ & $6.218 .885 .701,89$ \\
\hline $\mathbf{2 0 1 5}$ & $\begin{array}{c}\text { Termin IV } \\
10,6 \%\end{array}$ & $6.455 .877 .214,64$ & $4.252 .915 .383,23$ \\
\hline $\mathbf{2 0 1 5}$ & Termin V & & \\
\hline & $5 \%$ & & $2.006 .092 .161,90$ \\
& Total & $39.991 .874 .322,09$ & $40.121 .843 .238,00$ \\
\hline
\end{tabular}

\section{Metode Kontrak Selesai}

Bila digunakan Metode Kontrak Selesai, maka pada tahun 2014 tidak ada jurnal untuk mencatat pengakuan pendapatan, karena kontrak kerja untuk Proyek Block Office Batu belum selesai atau progress pekerjaan belum 100\%. Tetapi pada tahun 2015 kontrak kerja untuk Proyek Block Office Batu telah diselesaikan dan diserahkan kepada pemberi kerja atau owner, ditandai dengan pembayaran progress $100 \%$ dan retensi 5\%. Perhitungan pendapatan yang diakui pada tahun 2014 dan 2015 seperti terlihat pada Tabel 3. Dari Tabel 3 nampak bahwa pada tahun 2014 tidak ada penghasilan yang diakui. Penghasilan baru diakui pada tahun 2015, yaitu setelah pekerjaan selesai $100 \%$ yaitu sebesar Rp. 129.968.915,91.

Tabel 3

\section{Pengukuran Tingkat Penyelesaian} Kontrak Kerja

Proyek Block Office Batu

\begin{tabular}{|l|c|c|}
\hline \multicolumn{1}{|c|}{ Keterangan } & $\mathbf{2 0 1 4}$ & $\mathbf{2 0 1 5}$ \\
\hline Pendapatan diakui & - & 40.121 .843 .238 \\
\hline Biaya Konstruksi & - & $39.991 .874 .322,09$ \\
\hline $\begin{array}{l}\text { Penghasilan yang } \\
\text { diakui }\end{array}$ & - & $129.968 .915,91$ \\
\hline
\end{tabular}

\section{Metode Persentase Penyelesaian}

Bila perusahaan menggunakan Metode Persentase Penyelesaian, maka pengakuan pendapatan akan diakui setiap tahun sesuai dengan persentase pekerjaan yang telah diselesaikan. Dalam mengukur persentase pekerjaan yang telah diselesaikan dapat digunakan metode biaya ke biaya (cost to cost method). Pengakuan pendapatan 
untuk tahun 2014 dan tahun 2015 dengan menggunakan Metode Persentase Penyelesaian, di mana untuk mengukur persentase penyelesaian pekerjaan digunakan metode biaya ke biaya (cost to cost method) dapat dilihat pada Tabel 4. Pada Tabel 4 dapat dilihat bahwa penghasilan diakui pada tahun 2014 dan tahun 2015, yaitu pada saat persentase penyelesaian masingmasing mencapai 63\% dan 100\%. Besarnya penghasilan yang diakui pada tahun 2014 dan 2015 masingmasing sebesar Rp. 76.531.038,71 dan Rp. 53.437.877,20.

Tabel 4

\section{Pengukuran Tingkat Penyelesaian} Kontrak Kerja Proyek Block Office Batu

\begin{tabular}{|l|c|c|}
\hline \multicolumn{1}{|c|}{ Keterangan } & $\mathbf{2 0 1 4}$ & $\mathbf{2 0 1 5}$ \\
\hline Biaya pada periode & $25.200 .230 .201,23$ & $39.991 .874 .322,09$ \\
\hline $\begin{array}{l}\text { Tambahan taksiran } \\
\text { biaya penyelesaian }\end{array}$ & $14.791 .644 .120,86$ & - \\
\hline Biaya total & $39.991 .874 .322,09$ & $39.991 .874 .322,09$ \\
\hline $\begin{array}{l}\text { Estimasi persentase } \\
\text { selesai }\end{array}$ & $63 \%$ & $100 \%$ \\
\hline Harga Kontrak & 40.121 .843 .238 & 40.121 .843 .238 \\
\hline Pendapatan diakui & $25.276 .761 .240,94$ & 40.121 .483 .238 \\
\hline $\begin{array}{l}\text { Pendapatan diakui } \\
\text { tahun sebelumnya }\end{array}$ & - & $(25.276 .761 .240,94)$ \\
\hline $\begin{array}{l}\text { Pendapatan diakui } \\
\text { sekarang }\end{array}$ & $25.276 .761 .240,94$ & $14.845 .081 .998,06$ \\
\hline $\begin{array}{l}\text { Biaya yang diakui } \\
\text { sekarang }\end{array}$ & $25.200 .230 .201,23$ & $14.791 .644 .120,86$ \\
\hline $\begin{array}{l}\text { Penghasilan yang } \\
\text { diakui sekarang }\end{array}$ & $76.531 .038,71$ & $53.437 .877,20$ \\
\hline
\end{tabular}

\section{Hasil Analisa Data}

Dari penjabaran tersebut di atas, dapat dibuat perbedaan Laporan Laba Rugi antara Metode Kontrak Selesai dengan Metode Persentase Penyelesaian untuk Proyek Block Office Batu seperti terlihat pada Tabel 5.
Tabel 5

Perbandingan Laba Rugi Metode

Kontrak Selesai dan Metode Persentase Penyelesaian Proyek

Block Office Batu Tahun 2015

\begin{tabular}{|c|c|c|c|}
\hline Keterangan & $\begin{array}{c}\text { Metode } \\
\text { Kontrak } \\
\text { Selesai }\end{array}$ & \begin{tabular}{|c|} 
Metode \\
Persentase \\
Penyelesaian
\end{tabular} & Hasil Analisa \\
\hline $\begin{array}{l}\text { Pendapatan } \\
\text { Kontrak }\end{array}$ & 40.121 .843 .238 & 14.845 .081 .998 & $\begin{array}{l}\text { Pendapatan } \\
\text { kontrak yang } \\
\text { diakui dalam } \\
\text { metode kontrak } \\
\text { selesai adalah } \\
\text { sesuai nilai } \\
\text { kontrak tetapi } \\
\text { persentase } \\
\text { penyelesaian } \\
\text { mengakui setelah } \\
\text { pendapatan } \\
\text { dikurangi } \\
\text { pengakuan } \\
\text { pendapatan tahun } \\
\text { sebelumnya }\end{array}$ \\
\hline $\begin{array}{l}\text { Biaya yang } \\
\text { terjadi }\end{array}$ & 33.191 .874 .322 & 14.791.644.121 & $\begin{array}{l}\text { Pada metode } \\
\text { kontrak selesai } \\
\text { biaya yang terjadi } \\
\text { diakui secara } \\
\text { keseluruhan dari } \\
\text { awal proyek } \\
\text { sampai akhir } \\
\text { proyek tetapi } \\
\text { metode persentase } \\
\text { penyelesaian } \\
\text { diakui pada saat } \\
\text { tahun } 2015 \text { saja }\end{array}$ \\
\hline Laba Kotor & 129.968 .916 & 53.437 .877 & $\begin{array}{l}\text { Pada metode } \\
\text { kontrak selesai } \\
\text { pengakuan laba } \\
\text { diakui setelah } \\
\text { proyek selesai } \\
100 \% \text { tetapi } \\
\text { metode persentase } \\
\text { penyelesaian } \\
\text { mengakui laba } \\
\text { setelah dikurangi } \\
\text { pada laba tahun } \\
\text { sebelumnya }\end{array}$ \\
\hline
\end{tabular}

\section{KESIMPULAN}

Pengakuan pendapatan dengan Metode Persentase Penyelesaian yang menggunakan pendekatan proper matching concept (membandingkan biaya dan pendapatan secara layak) merupakan metode yang paling tepat untuk kontrak kerja jangka panjang dibandingkan Metode Kontrak Selesai, karena mengakibatkan Laporan Laba Rugi pada setiap periode dapat dilaporkan secara wajar.

Metode Persentase Penyelesaian sangat membantu perusahaan dalam 
mengatur keuangan perusahaan yang dalam satu periode bisa memiliki lebih dari satu kontrak kerja karena metode ini memperlihatkan Laporan Laba Rugi secara wajar.

\section{SARAN}

Perusahaan sudah seharusnya menggunakan metode pengakuan pendapatan dan beban berdasarkan Metode Persentase Penyelesaian baik itu untuk kontrak jangka pendek maupun untuk kontrak jangka panjang, karena metode ini sesuai dengan Pernyataan Standar Akuntansi Keuangan (PSAK) Nomor 34 tahun 2012 paragraf 24 yang menyatakan bahwa metode ini memberikan informasi yang berguna mengenai cakupan aktivitas kontrak dan kinerja selama suatu periode. Di samping itu alasan lain penggunaan metode ini karena metode ini sudah sesuai dengan peraturan perpajakan yang berlaku. Peraturan Pemerintah Nomor 94 tahun 2010 tanggal 30 Desember 2010 menyebutkan bahwa dengan Peraturan Direktur Jenderal Pajak dapat ditetapkan saat pengakuan penghasilan dan biaya dalam hal-hal tertentu sesuai dengan kebijakan Pemerintah yang mengacu pada pengakuan laba rugi perusahaan konstruksi.

\section{DAFTAR KEPUSTAKAAN}

Bastian, Bustami dan Nurlela, 2010, Akuntansi Biaya, Graha Ilmu, Yogyakarta.

Harahap, Sofyan Safri, 2011, Teori Akuntansi, Edisi Revisi, PT. Raja Grafindo Persada, Jakarta.

Ikatan Akuntansi Indonesia, 2012, Standar Akuntansi Keuangan, Ikatan Akuntan Indonesia, Jakarta.
Kieso, Donald E., Jerry J. Weygandt and Terry D. Warfield, 2011, Intermediate Accounting: IFRS Edition, Volume Dua, John Wiley \& Sons, New Jersey.

Martani, Dwi, 2012, Akuntansi Pajak Penghasilan, http://staff.blog.uc.ac. id, diakses tanggal 26 Desember 2015, pukul 18.45 .

Munawir, 2010, Analisis Laporan Keuangan, Edisi 4, Liberty, Yogyakarta.

Oktavia, Fransisca Amelia Heri, 2012, Analisis Metode Pengakuan Pendapatan Jasa Konstruksi Terhadap Perhitungan Laba Usaha PT. Ikanindo Rekatama Cipta di Surabaya, Skripsi, Fakultas Ekonomi, Universitas Katolik Darma Cendika, Surabaya.

Prianthara, Ida Bagus Teddy, 2010, Sistem Akuntansi Jasa Konstruksi, Graha Ilmu, Yogyakarta.

Prihadi, Toto, 2011, Praktis Memahami Laporan Keuangan Sesuai IFRS \& PSAK, Cetakan Pertama, PPM, Jakarta.

Purnomo, R. Serfianto Dibyo, Iswi Hariyani dan Cita Yustisia Serfiyani, 2011, Kitab Hukum Bisnis Properti, Cetakan Pertama, Pustaka Yustisia, Yogyakarta.

Putriandini, Nice Fifthantine, 2004, Pengaruh Pengakuan Pendapatan Terhadap Kewajaran Laporan Keuangan pada Perusahaan Kontraktor CV. Gemilang Jaya di Surabaya, Skripsi, Fakultas Ekonomi, Universitas Katolik Darma Cendika, Surabaya. 
Santoso, Iman, 2009, Akuntansi Keuangan Menengah (Intermediate Accounting), Cetakan Pertama, PT. Refika Aditama, Bandung.

Stice, James D., Earl K. Stice and K. Fred Skousen, 2010, Intermediate Ac-counting, $17^{\text {th }}$ Edition, SouthWestern, Cengage Learning, Mason, Ohio.
Supriyono, R.A., 2011, Akuntansi Biaya, Pengumpulan Biaya dan Penentuan Harga Pokok, Edisi 2, BPFE, Yogyakarta. 